Working Paper 9101

\title{
RISK-BASED CAPITAL AND DEPOSIT INSURANCE REFORM
}

by Robert B. Avery and Allen N. Berger

Robert B. Avery is an associate professor in the Department of Consumer Economics and Housing at Cornell University and a research associate at the Federal Reserve Bank of Cleveland. Allen N. Berger is a senior economist at the Board of Governors of the Federal Reserve System. The authors would like to thank Mark Carey, Sally Davies, Tess Ferg, Mark Flannery, David Jones, Kathy Kuester, Myron Kwast, Rich Rosen, James Thomson, and Greg Udell for helpful comments. They are also grateful to John Leusner for outstanding research assistance.

Working papers of the Federal Reserve Bank of Cleveland are preliminary materials circulated to stimulate discussion and critical comment. The views stated herein are those of the authors and not necessarily those of the Federal Reserve Bank of Cleveland or of the Board of Governors of the Federal Reserve System.

December 1990 


\begin{abstract}
Risk-based capital ( $R B C$ ) is an important component of deposit insurance reform. This paper provides an empirical analysis of the new 1992 RBC bank standards, applying them to data on virtually all U.S. banks from 1982 to 1989. The data reveal strong associations between several measures of future bank performance (including bankruptcy) and the RBC relative risk weights. These associations suggest that the weights constitute a significant improvement over the old capital standards, although there are several instances in which the weights for specific categories appear to be out of line with the performance results. Tests of the informational value of passing or failing the new and old capital standards show that both have independent information, but that the new RBC standards better predict future bank performance problems. The data also indicate that, in constrast to the old standards, the RBC capital burden falls much more heavily on large banks. As a result, banks representing more than one-fourth of all bank assets would have failed the new RBC standards as of 1989. The new standards are also more stringent overall. More banks would have failed the new standards than the old ones, with larger average capital deficiencies.
\end{abstract}




\section{Introduction}

The lessening of bank regulations in the early 1980s, the dramatic increase in depository institution failures in the middle and late 1980s, and the passage of the Financial Institutions Reform, Recovery, and Enforcement Act of 1989 (FIRREA) have heightened interest in depository institution insolvency risk and in the policy means to control this risk. One regulatory reform that preceded FIRREA was the international risk-based capital accord, which was adopted by bank regulatory agencies from 12 industrialized nations in 1988 . The guidelines mandate that U.S. banks be in full compliance by December 1992. Similar guidelines are currently being implemented for U.S. thrift institutions.

Risk-based capital (RBC) replaces capital guidelines that have required U.S. banks to hold a flat minimum percentage of capital against all assets since 1981. The risk-based standards, in contrast, require that different minimum capital percentages be held against different categories of assets according to their perceived risks. The new standards also require for the first time that capital be held against off-balance sheet activities. Another change is that the standards are largely uniform across all banks that operate internationally within the 12 participating nations.

RBC should be viewed not in isolation, but as part of an overall reform of the deposit insurance system, the primary goal of which is to reduce the incentives to undertake excessive risks that are inherent in the current flat-rate insurance regime. As will be shown below, $\mathrm{RBC}$ is a potential substitute for or complement to the risk discipline imposed by risk-based deposit insurance (RBDI) premia. In addition, the ability of RBC standards to reduce risk taking is related to the choice of accounting system (market value versus book value of capital), and can help to determine the effectiveness of bank examinations and policies to resolve problem institutions.

As with any capital standard, $\mathrm{RBC}$ is a form of coinsurance designed to reduce the costs of insolvency risk imposed on the federal deposit insurer by requiring a "buffer" of uninsured private funds to absorb portfolio losses. The major innovation of RBC is the requirement that more capital be held against portfolio items with higher perceived risk in order 
to provide incentives for banks to choose lower portfolio risk. This may be seen as implicit pricing of risk, since capital is a relatively costly source of funds, particularly when compared to insured deposits.

In large part, the success of RBC depends upon the extent to which the relative risk weights assigned to different portfolio categories correspond with the actual risks involved. If the correspondence is relatively tight, then the combination of the "buffer" value of the increase in capital and the incentives provided by the implicit pricing of portfolio risk is likely to be successful in reducing insolvency risk. However, if the correspondence between the risk weights and actual risks is relatively loose, or if there are significant areas in which higher risk categories receive lower risk weights, then some banks may have compelling incentives to increase portfolio risk, thereby possibly raising their insolvency risk.

To date, there has been little empirical analysis addressing this question of how the risk weights correspond to actual bank risk or examining the major features of RBC in order to determine their likely effects. ${ }^{1}$ This paper attempts to fill these gaps. We regress historical measures of bank performance, such as portfolio losses and bank failures, on the items in the $\mathrm{RBC}$ risk categories and test the appropriateness of the relative weights assigned. We also compare the ability of various measures of capital, including both the new and the old capital standards, to predict future bank performance. In addition, we examine the stringency of the new standards to determine whether they are likely to be effective in changing bank behavior.

The paper unfolds as follows. Sections II and III put the paper in perspective by reviewing the extant literature on capital standards and by comparing the relative advantages of RBC and RBDI, respectively. Section IV provides the empirical analysis in which measures of bank performance are regressed against RBC risk categories and subcategories in order to examine the efficacy of the RBC risk weights. Section V examines the stringency of the RBC standards by applying the 1992 standards to banks as of December 1989 . The

1. An exception is the contemporaneous work by Bradley, Wambeke, and Whidbee (1990), which examines RBC standards for thrifts. 
effects of changing the standards in various ways and the results of likely changes in bank portfolios are also calculated. Section VI concludes.

\section{Literature Review}

The extant literature on bank capital standards has 1) detailed their development and current specifications (e.g., Alfriend, 1988; Wall, 1989a), 2) analyzed their stringency and whether they were binding (e.g., Keeley, 1988; Keeton, 1989; Wall and Peterson, 1987), 3) examined the relative competitive effects of RBC across countries (e.g., Cooper, Kolari, and Wagster, 1990), 4) examined the extent to which one type of required capital, subordinated debt, imposes market discipline on banks (e.g., Avery, Belton, and Goldberg, 1988; Gorton and Santomero, 1990; Wall, 1989b), 5) examined how RBC might affect the supply of bank services (e.g., Haley, 1989), 6) examined how RBC might substitute for risk-based deposit insurance (e.g., Avery and Belton, 1987; Flannery, 1990; Ronn and Verma, 1988,1986), and 7) derived on a theoretical basis the circumstances under which capital requirements may increase or decrease bank portfolio or insolvency risk (e.g., Kim and Santomero, 1988; Koehn and Santomero, 1980; Furlong and Keeley, 1989; Keeley and Furlong, 1990; Keeton, 1988).

The most important question coming out of this literature is that of item (7)--whether increased capital standards increase or decrease bank risk. Virtually all authors agree that a mandatory increase in capital has the direct effect of reducing insolvency risk by providing an increased "buffer stock" of reserve funds to absorb losses. However, portfolio changes may also be induced, creating indirect effects on insolvency risk. Most authors also agree that when capital is below some sufficiently low level (perhaps negative), this indirect effect will also reduce insolvency risk, as the mandatory capital increase induces a reduction in portfolio risk by mitigating the moral hazard incentives to undertake excessive risk. However, authors sharply disagree upon whether banks in typical financial conditions will generally increase or decrease portfolio and insolvency risks as a result of increased capital requirements.

Kim and Santomero (1988) and Koehn and Santomero (1980), using a mean-variance utility maximization model, showed that an increase in flat-rate capital requirements restricts 
the risk-return tradeoff somewhat, but that banks might still choose higher-risk portfolios as a result of increased capital standards as they maximize utility along a restricted risk-return frontier. This occurs because banks may choose to take part of their reduction in utility from the loss in leverage as increased risk as well as lower expected return. It is even possible that insolvency risk may increase as a result of an increase in capital standards, defeating the purpose of the increase.

Furlong and Keeley (1989) and Keeley and Furlong (1990) followed a different approach, examining the case of a bank with publicly traded stock that maximizes the value of that stock. They found that such a bank will never increase portfolio risk, ceteris paribus, as a result of increased capital standards. This stands in direct contrast to the results of the meanvariance utility maximization model. A key feature of the Furlong and Keeley analysis is that under flat-rate deposit insurance, an increase in capital makes the bank take into account more of its prospective portfolio losses. In more technical terms, the capital increase reduces the value of the deposit insurance put option, the value of the bank's option to put part of its portfolio to the insurer in the event of failure and have the insurer repay its insured depositors in full. Furlong and Keeley objected to the mean-variance model because it assumed away the possibility of bank failure and changes in the value of the put option. However, Keeton (1988) showed that an increase in portfolio risk is quite possible as a result of increased capital standards, using a more general utility maximization model that includes the put option value. His analysis does not address the more important policy question of whether this increase in portfolio risk can be sufficient to offset the effect of increased capital in reducing bank insolvency risk. To our knowledge, no theory or example that includes the influence of the deposit insurance put option has yet been offered showing conditions under which increased capital requirements will result in increased bank insolvency risk.

Although the theoretical debate is ongoing, little has emerged from this literature to suggest that widespread increases in insolvency risk will occur as a result of increases in capital requirements. Insolvency risk increases do not occur in the stock value maximization model, 
and no studies have shown that such increases can occur in a utility maximization model that incorporates the put option value.

\section{A Comparison of Risk-Based Capital and Risk-Based Deposit Insurance}

Over the past several years, RBC and RBDI have been among the most prominently discussed methods of controlling bank risk, largely because they provide incentives for banks to reduce risk, rather than requiring direct intervention on the part of the insurer. Theoretically, either policy can reduce insolvency risk to virtually any level by placing sufficiently stiff penalties on risk through mandated increases in capital or insurance premia. Thus, as is well known, the same level of insolvency risk can be achieved by a well-implemented version of either policy (see Flannery, 1990; Ronn and Verma, 1988; Avery and Belton, 1987; Sharpe, 1978). Despite this equivalence, a number of important differences exist between $R B C$ and RBDI, especially when problems arise in setting the correct prices for either. We first examine the relative advantages of these policies when there are no pricing difficulties, and then discuss how these advantages change when some important pricing problems are introduced.

We assume throughout that the costs of raising capital are positively but imperfectly related to a bank's insolvency risk. For banks with traded stock, the imperfect relationship arises because of differential transactions costs in underwriting new issues, the loss of the deposit insurance subsidy, and, under the capital asset pricing model, the fact that the market only prices the part of risk that is correlated with the market portfolio. For small banks that do not trade, additional wedges in the relationship between risk and the cost of capital are created by problems such as a lack of diversification (which may induce considerable risk aversion), wealth constraints, and possible dilution of ownership and control.

2. The stock value maximization model may conform best to larger banks, which are usually publicly traded, and the utility maximization model may conform best to smaller, closely held banks. However, to the extent that there are significant agency problems between stockholders and managers, the utility maximization model may apply to both types of banks, as managers are risk averse with respect to their employment. 
A pure RBDI regime with no capital requirements would allow banks to choose both their portfolio risks and capital positions, and pay for the marginal social costs of the resulting insolvency risks. These social costs include not only the value of the deposit insurance put option, but also any other social costs arising from bank risk intemalized by the insurer, such as expected costs of liquidating failed banks, additional monitoring, and increased potential for financial instability. In the resulting equilibrium, banks with relatively high costs of capital or relatively good risky investment opportunities (i.e., a comparative advantage in high expected return/high risk portfolios), ceteris paribus, would tend to have higher insolvency risk and pay for this higher risk through greater insurance premia. To some degree, RBDI corrects the capital market's imperfect pricing of risk by allowing banks to trade off portfolio risk and capital at the socially appropriate relative price.

RBDI pricing can also incorporate social costs other than those created by bank insolvency risk. For instance, Flannery (1990) argued that high capital ratios resulting from either RBDI or RBC may reduce the intermediation of bank deposits into bank assets, which in tum may reduce some positive externalities from the intermediation process. In this event, optimal RBDI pricing would determine the optimal mix between insolvency risk and intermediation by setting a premium schedule that penalizes insolvency risk from high portfolio risk more than insolvency risk from low capital.

A pure RBC regime with flat-rate deposit insurance would have fewer degrees of freedom than pure RBDI to achieve a social optimum. Under RBC, banks are allowed to choose their portfolio risks directly, but not their capital positions or insolvency risks. Instead of explicitly pricing the social costs of insolvency risk, RBC implicitly prices portfolio risk by setting minimum capital requirements such that if the minimum is held, the marginal social costs of insolvency risk for each bank equal the flat-rate deposit insurance premium. Like pure RBDI, pure RBC can incorporate social costs other than those created by bank insolvency risk, including the loss of positive externalities from intermediation when capital is increased. 
Under these conditions, pure RBDI, which explicitly prices both capital and portfolio risks, dominates pure $\mathrm{RBC}$, which implicitly prices only portfolio risks. $\mathrm{RBC}$ creates a potential efficiency loss relative to RBDI, since the banks with the best risky portfolio opportunities and those with the lowest cost of capital may not be able to exploit their comparative advantages as well under RBC. This is because under pure RBDI a bank can trade off its portfolio risk and its capital position at the socially appropriate relative price, which is incorporated in the insurance premium schedule. In contrast, under pure RBC, banks must trade off between portfolio risk and capital at the relative price available to the bank in the market. This price may differ from the social optimum because of capital market imperfections, or because it does not incorporate the external social costs of risk or other factors. Another problem with $\mathrm{RBC}$ is that some banks may choose to hold more than the minimum required capital, so that the implicit pricing of risk through capital requirements has no effect on the marginal decisions of these banks. Thus, pure RBC can be as effective as pure RBDI in achieving a social optimum only if 1) the imperfections in the relationship between the cost of capital and bank risk are negligible, 2) the externalities from bank risk are negligible, and 3) no banks choose to hold capital in excess of the minimum requirements. Conditions (1) and (2) ensure that the bank can trade off portfolio risk and capital at the socially appropriate rate in the market, and condition (3) ensures that RBC can affect their marginal tradeoff at all. $^{3}$

Thus, when there are no difficulties in setting RBDI or RBC prices, pure RBDI with no capital requirements dominates $\mathrm{RBC}$ in the sense that RBDI can price any risk or other social cost at least as efficiently as RBC or any combination of RBDI and RBC. However, as shown below, a role for $\mathrm{RBC}$ appears as soon as pricing problems are introduced. We consider two such problems here: asymmetric information and policy inflexibility.

3. Note that we specifically rule out RBC schemes in which required capital is not monotonically increasing in the social costs of insolvency risk. This eliminates the possibility of "death penalties," such as occur if required capital is 100 percent unless portfolio risk is set at the the socially optimal level. 
We first relax the assumption of symmetric information. ${ }^{4}$ The insurer is generally at a significant information disadvantage relative to a bank in regard to its portfolio risk, since a principal reason for the existence of banks is to garner private information about the risk of its borrowers (see Diamond, 1984; Leland and Pyle, 1977). Bank examiners check the paperwork on only a sample of the assets and off-balance sheet contracts in the portfolio (see Udell, 1989), and even for these items, banks still may know their contractual counterparties and their own portfolio risk significantly better than the insurer does."

Asymmetric information opens the possibility for a productive role for $\mathrm{RBC}$ as a substitute for or complement to RBDI for several reasons. First, capital requirements may be viewed as a form of forced coinsurance. When a bank experiences portfolio losses, the owners bear the first tranche of losses, while the insurer bears part of one of the following tranches. To the extent that bank owners have better information on risk than does the insurer, capital standards improve the informational efficiency of (implicit) risk pricing, as the shadow price of risk provided by capital tends to give more accurate signals to reduce risk.

A second, related reason why $\mathrm{RBC}$ may be productive is that asymmetric information may exacerbate a moral hazard problem because the insurer cannot price any risk that it does not observe. By raising capital ratios for the least capitalized banks (which tend to have the greatest such moral hazard incentives), RBC may mitigate the problem by reducing the insurer's share of the cost of the bank's risk. ${ }^{7}$

4. It is assumed here that the only important informational asymmetry is between a bank and the insurer. If there are also important asymmetries between the bank and capital market participants, then an advantage of RBDI over RBC is that it allows the bank to signal its risk assessment to the market using its leverage ratio (see Campbell and Kracaw, 1980; Leland and Pyle, 1977).

5. Some have argued that there is also substantial independent uncertainty about the value of capital as well as about the value of the portfolio (e.g., Flannery, 1990), although these two values are obviously closely related.

6. The exact tranche of losses borne by the insurer depends upon state depositor preference laws, the implementation of bridge bank legislation, and the closure and purchase and assumption policies of the insurer.

7. Note that while RBC results in higher capital than RBDI for the least capitalized banks, either policy may result in more capital for the banking system as a whole. This follows from the fact that RBDI may reward banks for any increases in capital, while RBC does not reward capital increases above the minimum standards. 
Third, by raising capital ratios for the least capitalized banks, RBC may allow the insurer to gain more information about portfolio risk. For any given portfolio risk, the bank will take longer to fail if capital is higher. During this time, the fluctuations in capital from observed portfolio gains and losses or the results of on-site examinations may reveal information that allows the insurer to improve its estimate of portfolio risk and change the explicit or implicit price charged for risk. Under pure RBDI, a bank with very low capital may fail before much valuable information from this ex post monitoring is gamered.

Finally, asymmetric information provides a reason why RBC may complement RBDI. Flannery (1990) showed that when portfolio risk is imperfectly observed, there is error in estimating the put option value to use in pricing RBDI, and this error is decreasing in the capital ratio of the bank. RBC increases capital for the least capitalized banks with the most severe mispricing problems, which may reduce RBDI pricing errors and result in a better distribution of insurance premia and incentives.

We next relax the assumption that the insurer is completely flexible in responding to changes in bank insolvency risk. At best, $\mathrm{RBDI}$ premia and $\mathrm{RBC}$ requirements are set with a lag determined by reporting or examination intervals. ${ }^{8}$ In addition, government agencies often must follow strict rules that attach certain premia or capital requirements to objective reported criteria, such as balance sheet or income statement ratios, rather than using all the information learned through examination or market prices. These inflexibilities lend some relative advantages to both $\mathrm{RBDI}$ and $\mathrm{RBC}$.

In terms of explicit flexibjlity, RBDI has an advantage over RBC in that it has a shorter implementation lag. Banks can usually be made to pay a revised premium very quickly, whereas it may take considerable time to get new capital underwritten and sold to meet increased capital requirements. The difference is related to 1 ) the long and difficult process of

8. Sagari and Udell (1990) proposed reducing the effect of examination lags by letting banks determine their own RBDI premia and then checking on the accuracy of these premia through retrospective examinations. Ex post penalties are imposed when the premia were too low for a previous period. This procedure could apply as well to RBC. 
raising new capital and 2) the fact that the sheer number of dollars that must be raised for an increase in RBC capital is much greater than the corresponding RBDI premium increase.

In terms of implicit flexibility, by contrast, RBC may have an important advantage over RBDI for the least capitalized banks. Although the insurer may be bound by rules that do not allow responses to some publicly available information, market participants are not. An increase in insolvency risk that is publicly known will result in some market discipline through higher costs for raising equity capital and uninsured debt. The greater is the amount of these uninsured funding sources, the greater is the market discipline that automatically penalizes banks for increasing insolvency risk. RBC has more implicit flexibility than RBDI in pricing risk for banks with very low capital, since $\mathrm{RBC}$ requires these banks to hold more capital, and the market pricing of this capital will reflect observed risk without the necessity of rules. Although new equity capital is issued only infrequently, an equity standard implicitly prices risk continuously to the extent that the equity holders have control over management.

The analysis presented here suggests that pure RBDI is superior to pure RBC in terms of allocative efficiency when there are no information or policy implementation problems that create pricing errors. However, the best policy when these problems do occur may be neither pure RBDI nor pure RBC, but a combination of the two.

\section{Empirical Analysis of the Risk-Based Capital Standards}

The new RBC standards represent a significant change from past capital guidelines. Under the old standards effective since 1981, all banks were subject to the same minimum capital/asset ratios, irrespective of risk. Primary capital (equity, loan loss reserves, and some convertible debt and preferred stock) had to be at least 5.5 percent of total balance sheet assets, and total capital (primary capital plus subordinated debt and the remaining preferred stock) had to be at least 6 percent of assets. Under the new standards, by contrast, required capital ratios depend upon the perceived risk of the various assets and off-balance sheet activities.

9. See Ronn and Verma $(1986,1988)$ and Avery and Belton (1987) for comparisons of the sizes of required premia under RBDI and required capital under $\mathrm{RBC}$. 
Regulators have considered two methods of introducing risk into capital standards or deposit insurance premia. The method followed by the FDIC in its 1985 RBDI proposal (see Hirschhorn, 1986) focused on measures of current bank portfolio performance, such as earnings and asset quality. The new RBC standards, in contrast, focus on the current types of activities in bank portfolios. 10 This approach is based on the view that some activities are inherently more risky than others and therefore should be capitalized at higher levels. Under the new standards, on-balance sheet assets are allotted to one of four categories (A1 - A4) and each category is assigned a different relative risk weight, ranging from 0 to 100 percent (as shown in Table 1). Off-balance sheet activities also have a number of separate treatments. We weight them using the RBC relative weights and group them under two categories-counterparty guarantees (B1), where the bank guarantees the creditworthiness of another party (e.g., commitments, letters of credit), and market risk contracts (B2), where risk is principally determined by changes in market prices (e.g., interest rate swaps). The minimum capital level, $\mathbf{K}$, required under the standards is then defined as:

(1) $\mathrm{K}=\alpha(0.0 \cdot \mathrm{A} 1+0.2 \cdot \mathrm{A} 2+0.5 \cdot \mathrm{A} 3+1.0 \cdot \mathrm{A} 4+\mathrm{B} 1+\mathrm{B} 2)$,

where $\alpha$ is .04 for Tier 1 capital and .08 for total Tier 1 plus Tier 2 capital, and B1 and B2 incorporate the weights of their components. Tier 2 capital is restricted to be no larger than Tier 1 capital, which implies that all banks that fail the Tier 1 standard also fail the total standard (but not vice versa). A feature of the old capital standards is retained in a leverage requirement that Tier 1 capital must be at least 3 percent of (unweighted) on-balance sheet assets, although the actual requirement will be higher for some banks. 1

10. One exception is the new treatment of loan loss reserves as qualifying capital (see section V).

11. At the time of this writing, the Federal Reserve and OCC have recently implemented similar leverage policies that mandate minimum 3 percent Tier 1 capital to unweighted assets ratios for banks with the best examination rating (composite CAMEL = 1) that meet certain other conditions, with at least 1 to 2 percent additional capital for all other banks. The FDIC appears likely to implement a similar policy of 3 percent minimum for banks with the best rating that meet other conditions, with at least a 4 percent minimum for other banks. 
Critics have charged that the risk weights were somewhat arbitrarily chosen (e.g., the weighting of real estate loans at 50 percent rather than 100 percent) and may not necessarily reflect the true risks inherent in these different activities. In addition, the risk categories are very broad and may include items with quite different risks, particularly the 100 percent asset category which groups commercial loans of all qualities together. Moreover, the covariances among risks are not directly included, so in some circumstances, speculative portfolios may have the same capital requirements as hedged ones.

Despite these criticisms, however, if the higher weighted assets tend to have higher risk and if the off-balance sheet activities included create substantial risk, then the risk weights likely go significantly beyond the old flat-rate standards in identifying bank risk. It is also possible that even if the individual portfolio items do not cause risks in proportion to their risk weights, they are correlated with risks reasonably well in proportion to their weights. This would occur, for example, if banks with high percentages of Treasury securities or other zero-weight (A1) assets tend to have relatively low risk in their commercial loan portfolios or in their other full-weight (A4) assets.

It is clear that the efficacy of the risk weights is an empirical question, although to date there has been very little empirical analysis attempting to relate the $\mathrm{RBC}$ risk weights to actual bank risk. In this section, we examine this issue through the use of historical data on bank performance. We focus on the question of whether those assets assigned lower risk weights are associated with relatively "better" historical bank performance than those with higher weights. We also examine how failure to meet the RBC standards compares with failure to meet the old standards in predicting poor bank performance; that is, do the new standards truly take better account of risk differences across banks?

The ideal data set for this analysis would include information on the performance of individual loans, off-balance sheet contracts, and other portfolio items. Unfortunately, a comprehensive data set of this type is not available. As the best feasible altemative, we analyze the problem at the individual bank level, making a number of comparisons. Measures of the current performance of a bank--the rate of nonperforming loans (past due and nonaccruing), 
the net loan charge-off rate, the eamings rate (in level and standard deviation), and failure (bankruptcy)--are regressed against the lagged shares of bank assets and off-balance sheet items in each risk weight class. These regressions are designed to determine whether the weighting of assets under the new standards is consistent with the bank performance that is historically associated with these assets. We also run regressions to determine how failures to meet the new and old capital standards are associated with future bank performance.

Because the choice among bank performance measures is somewhat arbitrary, we include five different measures. Bank failure is the ultimate determinant of performance and is arguably the most appropriate measure to use in testing capital standards. Only in the event of bank failure does the insurer take a loss and are significant social costs generated. Moreover, some types of risk cannot be measured directly (e.g., propensity for fraud), but these are at least captured somewhat by the probability of failure. Each of the other measures captures one aspect of bank performance. Nonperforming loans is a stock measure reflecting the cumulative additions of poor loans. Charge-offs and earnings levels are flow measures, which may be more indicative of a bank's current performance. Earnings variability (standard deviation) reflects a longer-run view. While these are not exhaustive measures of performance, they should provide a reasonably broad-based test of the issues cited above.

Our analysis is based on Report of Condition and Income (Call Report) data measured annually on December 31 for the period 1982 to 1989 . We divide banks into two different samples for the analysis. The "small bank" sample consists of those with total adjusted assets (gross assets plus loan loss reserves) of less than $\$ 250$ million (in 1989 dollars) during the entire sample period. Any period in which the bank had real adjusted assets of less than $\$ 10$ million was eliminated, as were any periods in which primary capital was more than one-half of total assets. $^{12}$ The "large bank" sample consists of banks with real adjusted assets of more than $\$ 250$ million in at least one year. Together, the samples include data on virtually all

12. Very small banks and very highly capitalized banks often operate as specializing or shell banks that are atypical of bank behavior and therefore were excluded. In terms of total industry assets, these exclusions are trivial. 
U.S. commercial banks of significant size in existence during the past eight years. The decision to split the sample stemmed from strong historical evidence that risk and performance differ substantially across bank size classes.

The definition and sample means of the variables used are presented in Table 2. Each variable is scaled to ratio form by dividing by total adjusted bank assets. The INCOME, NONPERFORM, and CHARGEOFF performance variables are measured for each period from December 1983 through December 1989. If a bank failed in the year preceding a measurement date, it is excluded from the NONPERFORM and CHARGEOFF regressions. INCOME, however, is estimated in these cases and is the negative of existing capital at the end of the previous year minus the FDIC's estimated net outlay for the bank (taken from FDIC press releases). ${ }^{13}$ FAILURE, which reflects failure of the bank within two years of a given date, is measured with starting points of December 1982 to December $1988 .^{14}$ The independent variables--the risk categories and subcategories, dummies for failing the new and old standards, and time period dummies for each year--are measured from December 1982 through December 1988, a one year lag from the INCOME, NONPERFORM, and CHARGEOFF performance variables and an average lag of one year from the failures in the FAILURE performance variable. Because of the lag structure, the regressions using these variables will reflect the association between the independent variables and future bank performance. The time period dummies are included to control for systemwide changes in bank performance due to macroeconomic factors, changes in bank regulation, etc.

The regressions that use the standard deviation of eamings, INCOMESTD, are purely cross-sectional. The standard deviation is measured over all periods during which the bank was in existence and this variable is regressed against the average levels of each of the independent variables measured over the same interval.

13. This procedure avoids a potentially serious sample selection problem that might be created if income were excluded for failing banks (although this problem may still hold for the NONPERFORM and CHARGEOFF regressions).

14. The last observation is slightly truncated and includes failures only through March 1990. 
Overall, these procedures produced small and large bank sample sizes of 82,231 and 9,675 bank-years for the income and bank failure regressions; 81,457 small and 9,597 large bank-years for the nonperforming loan and charge-off regressions; and 13,169 small and 1,528 large bank cross-sectional observations for the income variability models.

Table 3 displays the regressions used to examine the appropriateness of the risk weights specified by the RBC standards. ${ }^{15}$ Two regressions are displayed for each dependent variable in each sample. The first regression includes variables representing the quantities in each risk category weighted by their risk weight: RWA20, RWA50, RWA100, COUNTER, and MKTRISK. The zero percent risk category is excluded as a base case, since it would have a weighted quantity of zero, and will be discussed further below. We also include variables for several risk subcategories weighted by their risk weights: REALEST, C\&I, CONSUMER, and COMMIT. The purpose of the latter variables is to test some of the more controversial aspects of the risk weights. The second regression includes the ratio of total risk-weighted assets to unweighted assets, RWA, as a single aggregate RBC measure. Both regressions include the time dummies.

These regressions test the appropriateness of the risk weights as follows. In all but the INCOME regressions, positive coefficients are expected for the risk categories if they are indeed associated with "poorer" bank performance. Moreover, if the RBC weights are appropriate in predicting performance, each of the coefficients of RWA20, RWA50, RWA100, COUNTER, and MKTRISK should be of the correct sign and equal. This equality is implied by the fact that the $\mathrm{RBC}$ weighting is already incorporated in the independent variables. In addition, if the RBC weights are correct, then the coefficients of the four risk subcategories, REALEST, C\&I, CONSUMER, and COMMIT, should be zero, since these quantities are already included with appropriate restrictions in the broader risk categories. The regression with

15. The regressions were estimated by OLS, but the standard errors were corrected for heteroskedasticity and serial correlation among the multiple error terms for an individual bank. Essentially, the procedure estimates a separate distribution for each bank using the exogenous variables and OLS residuals. This reduced the reported t-statistics considerably in most cases. 
the single coefficient for RWA shown just below the other regression for each dependent variable incorporates all the equality and zero restrictions on the risk categories and subcategories. Thus, if the risk weights are correct, the coefficients of RWA20, RWA50, RWA100, COUNTER, and MKTRISK should not be significantly different from the coefficient on RWA shown below, and fit of the two regressions should not be significantly different.

A comparison of the coefficients in the two regressions can also suggest which particular weights are inappropriate, and by how much. A risk category in the first regression with a coefficient of the same sign and higher absolute value as that of RWA in the second regression has more effect on performance than is indicated by its risk weight and may have been weighted too lightly. Similarly, a risk variable with lower absolute value or oppositesign coefficient to that of RWA likely has been weighted too heavily.

In general, the results suggest that the $\mathrm{RBC}$ variables have the correct signs predicting performance and that the risk weights have the correct relative ordering. ${ }^{16}$ In the regressions using the RWA variable (the ratio of risk-weighted assets to unweighted assets), the coefficient consistently indicated poorer performance (negative coefficient for INCOME, positive coefficient for INCOMESTD, NONPERFORM, CHARGEOFF, and FAIIURE) in all 10 cases and was statistically significant at the 5 percent level in 8 of the 10 cases. This strongly suggests that the $\mathrm{RBC}$ relative risk weights are an improvement over the equal weights of the old standards. $^{17}$ Specific findings of interest on the individual risk categories and subcategories from the more detailed regressions may be summarized as follows.

First, the controversial policy moving residential mortgage loans from the 100 percent risk category to the 50 percent category appears to be supported by the data. With the exception of the nonperforming loan regressions, the total coefficient of residential real estate loans

16. It should be noted that the overall fits of the regressions are relatively poor. This is caused in part by the decision to include only the variables reflecting the RBC standards. Many other variables that have been shown to predict future bank performance, such as asset and liability composition variables, were deliberately excluded. This is appropriate in performing tests of the RBC standards, since the standards contain no provisions to account for these other variables.

17. Note, however, that a joint test of all the exact restrictions on the individual risk categories and subcategories is rejected in all 10 cases. 
(the sum of the REALEST and RWA50 coefficients) implies that such loans should be weighted less heavily rather than more heavily. Indeed, by even wider margins, other assets in the $\mathbf{5 0}$ percent category standards (primarily municipal bonds) appear to be weighted too heavily as well. Second, evidence that we report elsewhere (Avery and Berger, 1988, 1991) showing that loan commitments are associated with better rather than poorer bank performance is supported by all 10 regressions in which COMMIT appears. In both samples, increased proportions of loan commitments (reflected by the sum of the coefficients of COMMIT and COUNTER) are associated with higher income, lower income variability, and fewer nonperforming loans, charge-offs, and failures. Note that this does not imply that risk is lowered by commitments, ceteris paribus, but rather that commitments are a signal of quality because better performing banks tend to issue more commitments. Interestingly, this better performance result also holds for other counterparty off-balance sheet items standards (primarily standby letters of credit), but only for large banks. For the small bank sample, these items appear to be positively associated with risk, although the $\mathrm{RBC}$ risk weight still appears to be too large. ${ }^{18}$ Third, assets in the 20 percent risk category appear to be weighted too lightly. This is particularly noticeable in the INCOMESTD and FAILURE regressions, and may reflect interest rate risk. ${ }^{19}$ Fourth, loans in the 100 percent category appear to have about the right relative weight, although part of this is by statistical construction, since RWA100 comprises more than 70 percent of RWA. Of the two separate components of this category examined, C\&I loans appear to be consistently associated with somewhat poorer performance than indicated by their 100 percent weight and may be weighted too lightly, while consumer loans have mixed results. Finally, the market risk off-balance sheet activities (MKTRISK) generally have very large relative coefficients that indicate better rather than worse bank performance, perhaps as a result of their use in hedging interest rate risk

18. The COUNTER results are generally consistent with those of Benveniste and Berger $(1986,1987)$, who found that the quantity of standby letters of credit issued was negatively related to bank risk for banks that participated in the standby market.

19. Explicit account of interest rate risk is under consideration for future versions of RBC. 
(particularly swaps). However, the findings may be unreliable for this variable because 1) the coefficients for the large banks are mainly statistically insignificant and 2) the coefficients for the small banks may be overly influenced by a few observations, since the vast majority of small banks have little or no contracts of this type (see Table 2).

No inferences about the appropriateness of the zero percent risk category (primarily cash and government securities) can be made from the regressions in Table 3, because these regressions test relative rather than absolute weights. A separate set of regressions (not displayed) was run to test the zero restriction. These regressions were similar to those in Table 3, except that the zero category was added and levels of the variables were used rather than ratios (ratios would create perfect collinearity). In general, the results support the zero restriction. Indeed, in all but 2 of 10 cases, negative weights for the zero percent category could be indicated because higher levels of zero category assets were associated with better bank performance. The two exceptions (large bank income and failure) were statistically insignificant.

Table 4 presents results indicating the informational value revealed when banks fail to meet various capital standards. The first set of regressions shows the effects on predicted bank performance of failing to meet any combination of the new and the old capital standards relative to passing both standards (the omitted category). The effect for banks failing both standards is given by the coefficients of OLD plus NEW; those failing only the new standards by NEW plus NEWONLY; and those failing only the old standards by OLD. As measured by INCOME, INCOMESTD, and FAILURE, the results consistently show that banks that would have failed both standards have poorer predicted performance in the following year relative to banks that failed only one or neither standard. Moreover, of the banks that failed only one standard, failure of the new standards appears to be a much better predictor of poor future performance. Interestingly, the results become much stronger in favor of the predictive power of the new standards in the NONPERFORM and CHARGEOFF regressions. Here, banks failing the new standard but not the old one show poorer or the same performance as those failing both standards. These are likely to be banks with very large loan 
loss reserves (penalized only under the new standards), which may signal greater than average loan problems in the future. 20

The second set of regressions presented in Table 4 sheds light on the relative predictive power of the three requirements of the new standard: Tier 1, total capital, and leverage. The data generally show that failing any of the three requirements indicates poorer performance. Of the 30 coefficients of FAILT1, FAILTOT, and FAILLEV, 28 are of the expected sign, although many of the coefficients are not statistically significant because of the strong collinearity. 21 Tuming to specifics, the data show that failing the Tier 1 standard predicts more pronounced future performance problems than failing the leverage requirement. The data also suggest that banks that fail the total capital standard but pass the Tier 1 standard are likely to perform better than those failing both standards and worse than those passing both standards. This is particularly true for small banks. Thus, the inclusion of Tier 2 capital in the $\mathrm{RBC}$ requirements appears to add important information.

The SHORTFALL variable, which measures the degree to which capital standards are violated, is included in order to form a crude test of "prompt resolution." Under prompt resolution policies, successively greater penalties (including closure) are applied to banks as they fall further below capital minimums. The data lend strong support to prompt resolution, with all 10 SHORTFALL coefficients indicating poorer future performance the greater is the degree to which the standards are violated ( 9 are statistically significant). The EXCESS variable, which measures the degree to which the capital standards are exceeded, provides a crude test of whether it may be appropriate to reward banks for holding capital beyond the minimum requirements through a reduced RBDI premium or other method. The results

20. Note that all the regressions reported in Table 4 include the risk category and subcategory variables. Although these coefficients are not shown, they are consistent with those shown in Table 3, indicating robustness of the relative risk weight results.

21. Recall that by construction, banks that fail the Tier 1 standard (FAIIT1=1) also fail the total standard (FAIITOT=1). Banks that fail the Tier 1 standard also very often fail the leverage requirement (FAILLEV=1), since they are based on the same capital definition (see section $V$ ). 
provide no clear support for such rewards. Except for the FAILURE regressions, the coefficients of EXCESS mostly predict poorer performance.

The relative predictive power of the capital standards is further illustrated by the raw data displayed in Table 5, which show the correspondence between failing the capital standards and the most important performance variable, FAILURE, over the two-year period in which the most bank failures occurred. More than 40 percent of the banks that failed both the old and new standards at the end of 1987 were bankrupt by the end of 1989 . Banks that failed only one of the two standards were significantly less likely than those failing both standards to go bankrupt in the following two years, although failing the new standards was the better predictor of the two. The bottom half of the table shows that of all the banks that failed one or more parts of the new capital standards, 32.3 percent went bankrupt over the next two years, as opposed to only 1.1 percent bankruptcies for those that passed all the new requirements. While all three portions of the new standards had some considerable predictive ability, the Tier 1 standard was overwhelming--more than 50 percent of the banks that failed this standard at the end of 1987 were bankrupt within two years.

Results presented in this section are quite robust to a number of variations that are not displayed. These include dropping the risk subcategories from the regressions in Tables 3 and 4, varying the time periods, adding dummies for size classes, adding independent variables lagged two years, and adjusting the performance measures in various ways, such as making the FAILURE variable cover one year instead of two. In no case did these variations substantively alter the basic conclusions.

\section{The Stringency of the Risk-Based Capital Standards}

Whether the new RBC standards are likely to be effective in changing bank behavior depends both upon the implicit relative capital prices that they impose (analyzed in the previous section), and upon the extent to which the new standards are more or less stringent than the old standards on individual banks (i.e., the change in absolute capital prices). To examine the stringency question, we apply both the 1992 RBC standards and the old standards to all 
U.S. banks as of December 1989. We investigate the extent to which the new standards are binding on different size classes of banks as compared to the old standards and examine the effects of tightening the new standards. We also look at which characteristics of the new standards are most important in making them binding. Finally, we examine which balance sheet and off-balance sheet activities account for the greatest burdens in terms of riskweighted assets and calculate the effects of some changes in portfolio behavior.

Table 6 shows the banks that fail to meet the new and old capital standards and each of the three components of the new standards, based on 1989 data. For a given size class of banks, each cell shows the proportion of banks that fail to meet the standards, the percent of the size class' assets represented by these banks, and the gross amount of capital by which these banks are deficient.

Comparison of the new and old standards in columns (1), (2), and (3) yields two major conclusions. First, the new standards will put pressure on a significantly different set of banks than the old standards, shifting the burden of capital requirements substantially onto larger banks. Institutions that failed the RBC standards in 1989 comprised 27.7 percent of all bank assets and were nearly eight times as large as those that passed, with nearly half of the banks in the largest size class (more than $\$ 10$ billion in assets) failing. By contrast, banks that failed the old standards comprised only 3.6 percent of all assets and were slightly smaller on average than those that passed. The contrast between the new and old standards with respect to bank size is also highlighted by the data shown in column (3), which shows the banks that failed the new standards but passed the old ones. Of the banks that failed the new standards, almost 40 percent passed the old standards, and these institutions accounted for nearly 90 percent of all the assets of banks failing the new standards. The remaining 125 banks that failed the old standards and passed the new ones (not shown) were very small, accounting for only 0.4 percent of all bank assets. A major reason for this size differential is that the larger banks had a much higher proportion of their portfolios in off-balance sheet activities, which did not have explicit capital requirements under the old standards. 
The second major conclusion is that the new standards appear to be more stringent than the old ones. Five hundred ninety-one banks failed the new standards, 22 percent more than the 484 that failed the old standards. In addition, the capital deficiency under the new standards was $\$ 15.1$ billion, more than six times the $\$ 2.4$ billion under the old standards. Despite these relatively large differences, however, it is not clear whether in the aggregate the new standards will be very difficult to meet. The $\$ 15.1$ billion aggregate capital deficit represents only 6 percent of the $\$ 256$ billion of Tier 1 and Tier 2 capital held by the industry in 1989 . For banks in the largest size class, which accounted for $\$ 10.8$ billion of the total deficiency, this represents 11 percent of their $\$ 96$ billion in capital. Note that the costs of compliance will be somewhat lower than the costs of raising these amounts of capital because of the flexibility of the RBC standards. In some cases, the cost of making portfolio adjustments to reduce required capital--such as substituting lower risk category assets for higher risk category assets, selling assets, or reducing off-balance sheet activities--will be less than the cost of raising additional capital. $^{2} 2$

Columns (4), (5), and (6) show the banks that failed to meet the three components of the new RBC requirements: Tier 1, total capital, and leverage. The total standard is clearly more binding than the Tier 1 standard, with 585 banks (representing 27.7 percent of all bank assets) having failed the total standard and only 259 banks (representing 5.2 percent of all bank assets) having failed the Tier 1 standard. Part of this dominance of the total standard is by construction, since banks that fail the Tier 1 standard must also fail the total standard. However, much of this result is also due to the fact that the old standards placed very little emphasis on the types of capital in Tier 2 . In 1989 , total Tier 1 capital was $\$ 200$ billion, while Tier 2 was only $\$ 56$ billion. Moreover, $\$ 30$ billion of the $\$ 56$ billion in Tier 2 capital was loan loss reserves, which counted as primary capital under the old standards.

22. Note also that because of some of the RBC capital restrictions, the capital deficiency is not always the amount that must be raised to meet the standards. For instance, if a bank is bound by the restriction that Tier 2 be no greater than Tier 1, a marginal $\$ 1$ raised of Tier 1 capital reduces the capital deficiency by $\$ 2$, and a marginal $\$ 1$ raised of Tier 2 capital leaves the capital deficiency unchanged. 
Column (6) shows the effect of a leverage requirement that banks hold Tier 1 capital of at least 3 percent of their unweighted total assets. This requirement appears to be very similar to the Tier 1 requirement, which requires the same type of capital. The main difference is that the leverage requirement falls less hard on the largest banks, since it neglects off-balance sheet items. However, the noteworthy fact is that the leverage requirement as applied here adds virtually nothing to the risk-based requirements. Only six small banks failed the leverage requirement that did not fail the risk-based requirements, making column (5) nearly identical to column (1).

Much discussion has focused on the levels of the Tier 1 and total capital requirements. Table 7 shows the effects of raising these standards on the various size classes of banks. Column (1) shows the new standards applied to 1989 data, and the succeeding columns report the effects of increasing the Tier 1 and total standards by 1, 2, 3, and 4 percent. Column (2) shows that increasing the standards to 5 percent for Tier 1 and to 9 percent for total capital virtually doubles the number of banks that would have failed to meet the standards for all size classes except the largest one and the smallest two. However, the aggregate total capital deficit rises only to $\$ 26$ billion, or about 10 percent of 1989 capital. As the capital requirements increase toward the $8 / 12$ standard shown in column (5), the increase in failures to meet the standards is relatively uniform, except for the largest size class. Nearly all of the largest banks would have failed by the $6 / 10$ standard. The most interesting result is how many of the small and even moderate-sized banks had sufficient capital to pass the 8/12 standard. Given that capital standards have never been near that range, it is surprising that more than half of the banks in each size class up to $\$ 500$ million would have passed this high standard. One reason for this result is that many of these smaller banks held capital in excess of the old standards and had relatively low risk-weighted assets, since they had little or no off-balance sheet 
activities. Finally, we note that the $\$ 83$ billion aggregate capital deficiency for the $8 / 12$ standards is substantial, 32 percent of 1989 capital. Most of this deficiency is in the largest size class, which had a shortfall of $\$ 52$ billion, or 54 percent of its capital. 23

We next examine the effects of what may be considered to be the four key innovations of the new RBC standards: 1) giving unequal weights to different asset categories, 2) including off-balance sheet activities in risk-weighted assets, 3 ) increasing the total amount of capital required, and 4) changing the treatment of loan loss reserves in the capital categories. We examine the influences of these innovations by "undoing" them one at a time, leaving all other aspects of the RBC standards unchanged. The top of Table 8 gives the figures for 1989 compliance with the new capital standards by all banks and also by banks in the largest size class. Row (1) in Panel A shows how many of the 1989 banks would have failed the RBC standards if all assets were given equal weights in risk-weighted assets; row (2) indicates the failure rate if off-balance sheet activities were excluded from the standards; row (3) shows the figures if the total amount of capital required were the same as under the old standards; and row (4) notes the results if loan loss reserves were counted as Tier 1 capital (instead of Tier 2) and were not restricted to 1.25 percent of risk-weighted assets. Note that for rows (1) and (2), where specific weights are changed, the weights are adjusted so that the required capital for the banking system as a whole remains unchanged. Thus, in row (1), the common capital weight applied to all assets is such that total systemwide assets require the same capital in 1989 as under RBC. In row (2), when off-balance sheet items are weighted at zero, the weights on all on-balance sheet assets are adjusted upward proportionately so that systemwide required capital is held constant.

The results in row (1) indicate that weighting the on-balance sheet assets equally instead of applying the RBC relative risk weights has little effect on the number of banks that would have failed the standards, increasing the total from 591 to 597 . However, there is a decrease in

23. The effects of increasing the leverage requirement from 3 to 6 percent were also calculated. A 6 percent leverage requirement would more than double the 1989 failures to meet the new standards, to 1,639 banks representing 56 percent of assets, including 37 of the 47 banks in the largest size class. This suggests that a high leverage requirement may have a dominating effect, even while the 3 percent requirement had virtually no effect. 
the number of the largest banks that would have failed (from 20 to 15), because these banks have relatively high proportions of their on-balance sheet assets in the 100 percent category. The effect of excluding off-balance sheet activities from the standards (row 2) would have increased the total number failing the standards from 591 to 915 , while decreasing large bank failures from 20 to 12 . This occurs primarily because off-balance sheet requirements shift a significant part of the total capital burden (held constant in the calculation) from the great number of smaller banks onto the relatively few large banks that dominate off-balance sheet markets.

The increase in total quantity of capital required under the new standards (row 3) is also important--only 481 banks would have failed the new standards had the aggregate required capital been kept at the level of the old standards. ${ }^{24}$ The effect of increased capital would have been much greater still had policy makers not shifted real estate loans from the 100 percent to the 50 percent category (without a corresponding change in the capital ratios): A calculation with real estate loans at 100 percent (not shown) would have increased the number of banks failing the standards to 875. Finally, allowing loan loss reserves to count fully in Tier 1 capital instead of restricting it in Tier 2 (row 4) would have decreased the number of banks failing the standards from 591 to 416, with a more than proportionate decrease for the largest banks from 20 to 11 . Additional calculations (not shown) indicate that virtually all of this effect is from the 1.25 percent restriction on reserves counting as capital, as opposed to counting them as Tier 2 instead of Tier 1 . Note that these restrictions on including loan loss reserves in required capital are the only way in which $\mathrm{RBC}$ takes account of the current performance of the bank's portfolio, as opposed to the types of activities within the portfolio. ${ }^{25}$

24. The increase in required total capital is equivalent to about .4 percent of assets, from 6.0 to 6.4 percent, since the ratio of total risk-weighted assets to unweighted assets is .8 and the new capital standards require 8 percent total capital in place of 6 percent.

25. Berger, Kuester, and O'Brien (1990) showed that if loan loss reserves were based more closely on portfolio performance measures (past due, renegotiated, and nonaccrual loans), the distribution of banks that fail the new standards would be substantially altered. 
Panel B of Table 8 examines the effects of some hypothetical changes in bank portfolios made as a result of $R B C$ in order to determine how successful such changes may be in meeting the standards without actually raising any capital. Row (5) shows the effect on compliance with the RBC standards of eliminating 10 percent of the assets in the 100 percent category. Banks could accomplish this by selling off loans or other assets in the 100 percent category, by substituting some lower risk category assets for higher risk category assets, or by making adjustments to some assets (e.g., securing more loans with 1-4 family residences). Row (6) shows the effect of eliminating half of all loan commitments with maturities of more than one year and half of all standbys issued to nonfinancial firms. These off-balance sheet changes approximate the effects of shifting half of all long-term commitments and all standbys backing commercial paper to commitments of one year or less (which have a zero weight). Row (7) combines these on- and off-balance sheet changes. The results suggest that quite a few banks may be able to meet the RBC standards in large part or in full by making on-balance sheet portfolio changes, but that the potential for meeting the standards by offbalance sheet adjustments is more limited, except for the largest banks.

\section{Conclusion}

This paper uses historical data on the relationship between bank performance and portfolio behavior to analyze the new risk-based capital program. We test the RBC relative risk weights by regressing several measures of bank performance, including bankruptcy, on the proportions of bank portfolios in each of the risk categories one year prior, using data from 1982 to 1989 . The data strongly suggest that the relative risk weights constitute an improvement over the old capital standards of equal weights for ail assets. In all cases, banks with higher ratios of risk-weighted assets to unweighted assets have poorer predicted performance, and most of these results are statistically significant. However, we also find several instances in which the risk weights for specific categories appear to be out of line with the performance results. An implication of these findings is that a risk-based deposit insurance scheme that uses the same portfolio risk-weights as the new RBC program (plus 
some rewards for higher amounts of capital) would likely constitute an improvement over the current flat-rate deposit insurance scheme, although there may be room for even further improvement by altering some of the risk weights and possibly including measures of bank performance.

Similar tests of the informational value of different capital standards suggest that both the new and old capital standards have independent information in predicting future bank performance problems, but that the new standards have more information. The data also indicate that there may be independent information in each of the Tier 1 and total capital components of the new standards. The leverage requirement as it is applied here adds virtually no new information, since almost every bank that fails it also fails one of the other RBC requirements. The degree to which banks fail the new standards is found to be a good predictor of future performance problems, lending support to "prompt resolution" policies to take action against banks based on the degree to which the standards are violated. Surprisingly, the degree to which banks exceed the standards is not found to predict better future performance.

Examination of the stringency of the new RBC standards shows that they fall much more heavily on large banks than do the old standards, with the banks that fail the new standards representing more than one-fourth of all banking industry assets. This occurs because large banks have higher proportions of their portfolios in highly capitalized items, particularly off-balance sheet activities. The RBC standards are also more stringent than the old standards in absolute terms, with more banks failing the new standards, and failing them with a much larger capital deficiency. Nonetheless, the new standards still require only a small increase in capital relative to the current stock. Of the major innovations of RBC, only the more conservative treatment of loan loss reserves as capital and the overall increase in capital required raised the aggregate stringency of the standards significantly. Calculations of portfolio reactions to $R B C$ suggest that many banks may be able to meet the new standards in part or in full by adjusting their asset holdings, but that there is limited scope for using offbalance sheet adjustments to meet the standards. 
It must be cautioned that because the results reported here are based on historical associations, care must be taken in extrapolating any conclusions about future bank performance and behavior. Once the RBC regulations are fully in place, banks will be reacting to different relative and absolute prices than those embodied in our data set, and this could change the results significantly. Nonetheless, we believe that our basic findings about the appropriateness of the $\mathrm{RBC}$ relative risk weights, the informational content of the new and old standards, and the shifts in the stringency of the standards are sufficiently conclusive to hold up over time. 


\section{REFERENCES}

Alfriend, Malcolm C., "Intermational Risk-Based Capital Standard: History and Explanation," Economic Review, Federal Reserve Bank of Richmond, Richmond, VA (November/December 1988): 28-34.

Avery, Robert B., and Terrence M. Belton, "A Comparison of Risk-Based Capital and RiskBased Deposit Insurance," Economic Review, Federal Reserve Bank of Cleveland, Cleveland, OH (Fourth Quarter 1987): 20-30.

Avery, Robert B., Terrence M. Belton, and Michael A. Goldberg, "Market Discipline in Regulating Bank Risk: New Evidence from the Capital Markets," Journal of Money, Credit and Banking 20 (November 1988): 597-610.

Avery, Robert B., and Allen N. Berger, "Risk-Based Capital and Off-Balance Sheet Activities," Proceedings of a Conference on Bank Structure and Competition, Federal Reserve Bank of Chicago, Chicago, IL (1988): 261-87.

Avery, Robert B., and Allen N. Berger, "Loan Commitments and Bank Risk Exposure," Journal of Banking and Finance, forthcoming, 1991.

Benveniste, Lawrence M., and Allen N. Berger, "An Empirical Analysis of Standby Letters of Credit," (with L. Benveniste), Proceedings of a Conference on Bank Structure and Competition, Federal Reserve Bank of Chicago, Chicago, IL (1986): 387-412.

Benveniste, Lawrence M., and Allen N. Berger, "Securitization with Recourse: An Instrument that Offers Uninsured Bank Depositors Sequential Claims," Journal of Banking and Finance 11 (September 1987): 403-24.

Berger, Allen N., Kathleen A. Kuester, and James M. O'Brien, "The Limitations of Market Value Accounting and a More Realistic Alternative," working paper, Board of Governors of the Federal Reserve System, Washington, DC, September 1990.

Bradley, Michael G., Carol A. Wambeke, and David A. Whidbee, "Risk Weights, Risk-Based Capital, and Deposit Insurance," working paper, Office of Thrift Supervision, Washington, DC, September 1990.

Campbell, Tim S., and William A. Kracaw, "Information Production, Market Signalling, and the Theory of Financial Intermediation," Journal of Finance 35 (September 1980): 863882. 
Cooper, Kerry, James Kolari, and John Wagster, "A Note on the Stock Market Effects of the Adoption of Risk-Based Capital Requirements on International Banks in Different Countries," working paper, Texas A\&M University, September 1990.

Diamond, Douglas W., "Financial Intermediation and Delegated Monitoring," Review of Economic Studies 51 (July 1984): 393-414.

Flannery, Mark J., "Pricing Deposit Insurance When the Insurer Measures Bank Risk with Error," working paper, University of Florida, June 1990.

Furlong, Frederick T., and Michael C. Keeley, "Capital Regulation and Bank Risk-Taking: A Note," Journal of Banking and Finance 13 (December 1989): 883-91.

Gorton, Gary, and Santomero, Anthony M., "Market Discipline and Bank Subordinated Debt," Journal of Money, Credit and Banking 22 (February 1990): 119-28.

Haley, Charles W., "The Impact of Risk-Based Capital Requirements on the Supply of Bank Services," working paper, University of Washington, October 1989.

Hirschhorn, Eric, "Developing a Proposal for Risk-Related Deposit Insurance," FDIC Banking and Economic Review (September/October 1986): 3-10.

Keeley, Michael C., "Bank Capital Regulations in the 1980s: Effective or Ineffective?" Proceedings of a Conference on Bank Structure and Competition, Federal Reserve Bank of Chicago, Chicago, IL (1988): 91-111.

Keeley, Michael C., and Frederick T. Furlong, "A Reexamination of Mean-Variance Analysis of Bank Capital Regulation," Journal of Banking and Finance 14 (March 1990): 69-84.

Keeton, William R., "Substitutes and Complements in Bank Risk-Taking and the Effectiveness of Regulation," working paper, Federal Reserve Bank of Kansas City, Kansas City, MO, December 1988.

Keeton, William R., "The New Risk-Based Capital Plan for Commercial Banks," Economic Review, Federal Reserve Bank of Kansas City, Kansas City, MO (December 1989): 4060.

Kim, Daesik, and Anthony M. Santomero, "Risk in Banking and Capital Regulation," Journal of Finance 43 (December 1988): 1219-33.

Koehn, Michael, and Anthony M. Santomero, "Regulation of Bank Capital and Portfolio Risk," Journal of Finance 35 (December 1980): 1235-44. 
Leland, Hayne E., and David H. Pyle, "Informational Asymmetries, Financial Structure, and Financial Intermediation," Journal of Finance 32 (May 1977): 371-87.

Ronn, Ehud I., and Avinash K. Verma, "Pricing Risk-Adjusted Deposit Insurance: An OptionBased Model," Journal of Finance 41 (September 1986): 871-95.

Ronn, Ehud I., and Avinash K. Verma, "Risk-Based Capital Adequacy Standards for a Sample of 43 Major Banks," Proceedings of a Conference on Bank Structure and Competition, Federal Reserve Bank of Chicago, Chicago, IL (1988): 79-90.

Sagari, Sylvia, and Gregory F. Udell, "Bank Examinations, Ex Post Monitoring, and Deposit Insurance Reform," working paper, New York University, 1990.

Sharpe, William F., "Bank Capital Adequacy, Deposit Insurance and Security Values," Journal of Financial and Quantitative Analysis 13 (November 1978): 701-18.

Udell, Gregory F., "Loan Quality, Commercial Loan Review and Loan Officer Contracting," Journal of Banking and Finance 13 (May 1989): 367-82.

Wall, Larry D., "Capital Requirements for Banks: A Look at the 1981 and 1988 Standards," Economic Review, Federal Reserve Bank of Atlanta, Atlanta, GA (March/April 1989a): 14-29.

Wall, Larry D., "A Plan for Reducing Future Deposit Insurance Losses: Puttable Subordinated Debt," Economic Review, Federal Reserve Bank of Atlanta, Atlanta, GA (July/August 1989b): 2-17.

Wall, Larry D., and David R. Peterson, "The Effect of Capital Adequacy Requirements on Large Bank Holding Companies," Journal of Banking and Finance 11 (December 1987): 581-600. 
Table 1

SOLARY OF THE IIA RISK-BASED CAPITAL STANDARDS

\section{RISK CATECORImS}

Category $\mathbf{A 1}$ (0 percent weight)

Cash, Federal Reserve Bank balances

Securities of the U.S. Treasury, OECD governments, and some U.S. agencies

Category 12 (20 percent weight)

Cash items in the process of collection

O.S. and OECD interbank deposits and guaranteed claims

Some non-OECD bank and government deposits and securities

General obligation municipal bonds

Some mortgage-backed securities

Claims collateralized by the U.S. Treasury and some other government securities

Category $\mathbf{A 3}$ (50 percent weight)

Loans fully secured by first liens on 1-4 family residential properties

Other (revenue) municipal bonds

Category A4 (100 percent weight)

All other on-balance sheet assets not listed above, including:

loans to private entities and individuals, some claims on non-OECD

governments and banks, real assets, and investments in subsidiaries

Category B1 (off-balance sheet counterparty guarantees; weights in parentheses) Direct-credit-substitute standby letters of credit (mainly 100 percent)

Performance-related standby letters of credit (mainly 50 percent)

Unused portion of loan commitments with original maturity of more than one year (mainly 50 percent)

Other loan commitments ( 0 percent)

Commercial letters of credit (20 percent)

Bankers acceptances conveyed (20 percent)

Category B2 (off-balance sheet market risk contracts; weights in parentheses)

Interest rate swaps, forward commitments to purchase foreign exchange and other items (between 0 and 5 percent of the notional value, plus the mark-to-market value of the contract, capped at 50 percent)

\section{CAPITAL REOOIRERIATS}

Tier 1

Common equity, some preferred stock, minority interest in consolidated subsidiaries less goodwill.

Tier 2

Tier 1 capital must be at least 4 percent of risk-weighted assets.

Loan loss reserve (limited to 1.25 percent of risk-weighted assets), subordinated debt (limited to 50 percent of Tier 1), and other preferred and convertible stock.

Tier 2 capital cannot be larger than Tier 1 capital.

Tier 1 plus Tier 2 capital must be at least 8 percent of risk-weighted assets.

Ieverage Requirement

Tier 1 capital must be at least 3 percent of total on-balance sheet assets (will be higher for banks with poor examination ratings and for those not meeting certain conditions, a fact not incorporated here; see text, fn. 11 ). 


\section{PERTORLANC: MEASURES}

Incoses

Ratio of net income to total adjusted assets. when failure occurs, INCOME is estimated as the negative of capital in period $t$ minus the FDIC' $s$ estimated outlay.

INCOMmSTD Sample standard deviation of INCOME for each bank.

$.0135 \quad .0110$

NOARERTORM Ratio of nonperforming loans (past due and

$.0290 \quad .0313$

nonaccruing) to adjusted assets.

CARRE:OFT Ratio of net loan charge-offs to adjusted assets.

$.0059 \quad .0058$

EAIIURE

Dummy, equals one if the bank fails within 2 years

$.0192 \quad .0171$ hence. The December 1988 observation includes failures only through March 1990.

\section{RISK-WEIGEYTD ASSET CATECORIES ${ }^{b}$}

\begin{tabular}{|c|c|c|c|}
\hline $\operatorname{RtA} 20$ & $\begin{array}{l}0.2 \text { times ratio of } 20 \text { percent weight on-balance } \\
\text { sheet assets to adjusted assets. }\end{array}$ & .0352 & .0361 \\
\hline RLA50 & $\begin{array}{l}0.5 \text { times ratio of } 50 \text { percent weight on-balance } \\
\text { sheet assets to adjusted assets. }\end{array}$ & .0801 & .0762 \\
\hline $\operatorname{RMA100}$ & $\begin{array}{l}1.0 \text { times ratio of } 100 \text { percent weight on-balance } \\
\text { sheet assets to adjusted assets. }\end{array}$ & .4734 & .5323 \\
\hline COUNIYHR ${ }^{C}$ & $\begin{array}{l}\text { Ratio of counterparty off-balance sheet assets } \\
\text { (appropriately weighted) to adjusted assets. }\end{array}$ & .0086 & .0342 \\
\hline MLIRISK ${ }^{C}$ & $\begin{array}{l}\text { Ratio of market risk off-balance sheet assets } \\
\text { (appropriately weighted) to adjusted assets. }\end{array}$ & .0000003 & .00005 \\
\hline \multirow[t]{2}{*}{ RNA } & $\begin{array}{l}\text { Ratio of total risk-weighted assets to adjusted } \\
\text { assets. }\end{array}$ & .5972 & .6788 \\
\hline & RI8K-MEIGHYHD ASSET SOBCATRCORIES & & \\
\hline RHATEST & $\begin{array}{l}0.5 \text { times ratio of } 1-4 \text { family real estate loans to } \\
\text { adjusted assets. }\end{array}$ & .0556 & .0513 \\
\hline CEI & $\begin{array}{l}1.0 \text { times ratio of commercial and industrial loans } \\
\text { to adjusted assets. }\end{array}$ & .0453 & .1682 \\
\hline COASOUIER & 1.0 times ratio of consumer loans to adjusted assets. & .1167 & .1392 \\
\hline covarty & $\begin{array}{l}\text { Ratio of loan commitments (adjusted by their risk- } \\
\text { weighted asset weights) to adjusted assets. }\end{array}$ & .0054 & .0237 \\
\hline
\end{tabular}


Symbol $\quad \underline{\text { Definition }}$

SEE AND OID CAPITAL STARDARD FAILURE DUMIIES

NEW

OID

NEFONLYY

Dummy, equals one for failing any portion of the new capital standard.

Dummy, equals one for failing either the primary or

$.0329 \quad .0815$ the total capital portion of the old standard.

Dummy, equals one for failing any portion of the new standard and passing the old standard.

\section{NEH CAPITAL STANDARD FAILURA COMPONINTS}

FAILT1 Dummy, equals one for failing Tier 1 standard. $.0138 \quad .0179$

FAIITOT Dummy, equals one for failing total standard. $.0338 \quad .1016$

TAIIIEV Dummy, equals one for failing leverage standard. $.0154 \quad .0160$ SHORTEALI Ratio of capital shortfall (maximum of capital deficiency in meeting leverage or total standards) $.0008 \quad .0014$ to adjusted assets. Zero if the bank does not fail either part of the standards.

Excess

Ratio of excess capital (the minimum overage of the leverage and total standards) to adjusted assets.

a. Total adjusted assets are total assets plus loan loss reserves.

b. A number of assumptions had to be made to construct historically consistent series for these variables, since they do not correspond exactly to Call Report categories. Details of these calculations are available from the authors.

c. For 1982, the only off-balance sheet item available was standby letters of credit. For CounTer, this essentially means that loan commitments (the only other substantial element of COUNTER) was missing for this year. A zero was included for this year for MKTRISK, which was zero for most of the banks and substantial for only a few.

Sources: Federal Reserve Reports of Condition and Income, FDIC press releases. 
InCOW. InCOWr 810 BOAPERTOM CMARELOTI IAIIORT Variable Parameter t-stat Parameter t-otat Parameter $t$-stat Parameter $t$-stat Parameter $t$-stat gnst RMits

\begin{tabular}{|c|c|c|c|c|c|c|c|c|c|c|}
\hline INIYRCAPT & .0328 & 35.77 & -.0304 & 15.95 & -.0235 & 26.23 & -.0075 & 24.74 & -.0871 & 19.06 \\
\hline $\operatorname{RtA20}$ & -.1021 & 13.19 & .1402 & 8.68 & .0715 & 8.58 & .0109 & 2.74 & .2343 & 6.09 \\
\hline RLASO & .2029 & 37.86 & -.1214 & 8.74 & -.0621 & 9.83 & -.0196 & 10.42 & -.3255 & 14.48 \\
\hline $\operatorname{TLA100}$ & -.0517 & 34.07 & .0874 & 31.50 & .0805 & 61.49 & .0233 & 53.42 & .1828 & 23.63 \\
\hline COONIILR & -.0295 & 2.25 & .1702 & 4.89 & .0475 & 2.92 & -.0018 & .44 & .1077 & 1.71 \\
\hline MLIRISK & 34.5833 & 3.13 & -49.2466 & 1.78 & -54.2121 & 7.90 & -7.1865 & 2.43 & -62.7980 & 1.71 \\
\hline RENTEST & -.2223 & 37.51 & .1480 & 10.67 & .1823 & 25.09 & .0144 & 7.03 & .4189 & 15.76 \\
\hline CeI & -.0047 & 1.76 & $\begin{array}{r}.0603 \\
-\quad 0220\end{array}$ & $\begin{array}{r}12.86 \\
7.06\end{array}$ & .0160 & $\begin{array}{r}6.73 \\
2.77\end{array}$ & $\begin{array}{r}.0009 \\
0008\end{array}$ & 1.16 & $\begin{array}{r}.0176 \\
-\quad 0548\end{array}$ & 1.21 \\
\hline Coviry & .1670 & 8.91 & -.5651 & 12.13 & -.1577 & 7.45 & -.0510 & 8.54 & -.7040 & 7.68 \\
\hline 1984 & -.0027 & 9.96 & -- & - & .0033 & 13.91 & .0010 & 10.60 & .0064 & 6.54 \\
\hline 1985 & -.0079 & 19.13 & - & - & .0124 & 31.67 & .0049 & 33.87 & .0237 & 10.99 \\
\hline 1986 & -.0106 & 24.36 & -- & -- & .0106 & 27.18 & .0059 & 39.20 & .0318 & 14.48 \\
\hline 1987 & -.0107 & 23.86 & -- & -- & .0066 & 17.14 & .0038 & 27.64 & .0367 & 16.03 \\
\hline 1988 & -.0087 & 18.65 & -- & -- & .0041 & 9.89 & .0026 & 16.24 & .0372 & 15.47 \\
\hline 1989 & -.0068 & 14.43 & $\sim$ & - & .0028 & 6.95 & .0017 & 12.89 & .0252 & 11.51 \\
\hline R sguared & \multicolumn{2}{|c|}{.086} & \multicolumn{2}{|c|}{.170} & \multicolumn{2}{|c|}{.178} & \multicolumn{2}{|c|}{.126} & \multicolumn{2}{|c|}{.036} \\
\hline INIY RCIPY & .0398 & 45.28 & -.0397 & 30.47 & -.0246 & 32.78 & -.0101 & 36.15 & -.0097 & 22.81 \\
\hline BGA & -.0477 & 35.01 & .0883 & 41.49 & .0817 & 69.23 & .0225 & 51.90 & .1622 & 24.17 \\
\hline 1984 & -.0026 & 9.87 & - & - & .0030 & 13.56 & .0009 & 9.47 & .0046 & 5.08 \\
\hline 1985 & -.0078 & 23.28 & -- & -- & .0109 & 35.21 & .0046 & 36.83 & .0198 & 12.57 \\
\hline 1986 & -.0010 & 28.01 & -- & -- & .0090 & 29.23 & .0054 & 40.52 & .0270 & 15.01 \\
\hline 1987 & -.0011 & 28.06 & -- & -- & .0054 & 17.15 & .0034 & 27.06 & .0334 & 16.99 \\
\hline 1988 & -.0095 & 23.55 & -- & -- & .0033 & 10.32 & .0021 & 15.81 & .0338 & 17.00 \\
\hline 1989 & -.0078 & 19.93 & -- & -- & .0022 & 7.44 & .0011 & 10.52 & .0219 & 13.29 \\
\hline $\begin{array}{l}\text { R mquared } \\
\text { Nom. Obe. }\end{array}$ & 82 & & 13 & & $8 i^{1}$ & & 81 & & 82 & \\
\hline
\end{tabular}

INRE BATLS

\begin{tabular}{|c|c|c|c|c|c|c|c|c|c|c|}
\hline IHY tretpI & .0135 & 3.75 & -.0156 & 2.13 & -.0285 & 2.70 & -.0122 & 2.59 & -.0577 & 3.37 \\
\hline $\operatorname{Exn20}$ & -.0473 & 1.46 & .1434 & 2.83 & .5945 & 2.05 & .1608 & 1.79 & .6000 & 3.39 \\
\hline Danso & .1990 & 9.26 & -.2215 & 4.64 & -.3711 & 3.76 & -.0873 & 6.41 & -.4400 & 4.84 \\
\hline $\operatorname{Rma100}$ & -.0327 & 5.34 & .0773 & 7.54 & .0981 & 5.99 & .0227 & 6.35 & .1720 & 5.96 \\
\hline COONHER & .0431 & 1.56 & -.0551 & .77 & -.0943 & 1.21 & -.0110 & .58 & -.3918 & 2.54 \\
\hline MSTRI8K & -.1728 & .35 & -1.7239 & .78 & -.3406 & .33 & -.1304 & .44 & -5.2817 & 2.28 \\
\hline BUATEST & -.1721 & 7.85 & .2040 & 4.48 & .4774 & 4.86 & .0825 & 4.46 & .3563 & 4.02 \\
\hline $\operatorname{ceI}$ & .0001 & .01 & -.0232 & 2.11 & -.0515 & 2.89 & -.0099 & 2.56 & -.0486 & 1.22 \\
\hline CONBOATR & .0408 & 6.49 & -.0391 & 5.18 & -.0169 & 1.23 & .0170 & 3.41 & -.1546 & 5.45 \\
\hline conerr & .0145 & .47 & -.0826 & .95 & .0054 & .08 & -.0190 & 1.10 & .1703 & 1.00 \\
\hline 1984 & -.0003 & .38 & - & - & .0033 & 1.74 & .0012 & 2.21 & .0050 & 1.89 \\
\hline 1985 & .0004 & .43 & $m$ & -- & .0025 & 1.20 & .0016 & 2.25 & .0084 & 2.13 \\
\hline 1986 & -.0028 & 2.85 & -- & -- & .0088 & 2.71 & .0044 & 4.50 & .0153 & 3.42 \\
\hline 1987 & -.0032 & 2.65 & -- & - & .0127 & 1.34 & .0044 & 3.13 & .0289 & 4.86 \\
\hline 1988 & -.0033 & 2.57 & - & - & -.0002 & .07 & .0031 & 2.48 & .0411 & 5.86 \\
\hline 1980 & -.0007 & .60 & -- & -- & .0023 & .41 & .0042 & 1.47 & .0190 & 3.29 \\
\hline R equared & \multicolumn{2}{|c|}{.060} & \multicolumn{2}{|c|}{.104} & \multicolumn{2}{|c|}{.014} & \multicolumn{2}{|c|}{.035} & \multicolumn{2}{|c|}{.043} \\
\hline 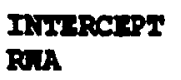 & $\begin{array}{r}.0185 \\
-.0152\end{array}$ & $\begin{array}{l}8.55 \\
4.47\end{array}$ & $\begin{array}{r}-.0123 \\
.0344\end{array}$ & $\begin{array}{l}3.28 \\
6.29\end{array}$ & $\begin{array}{l}.0135 \\
.0221\end{array}$ & $\begin{array}{l}.71 \\
.75\end{array}$ & $\begin{array}{r}-.0035 \\
.0109\end{array}$ & $\begin{array}{r}.78 \\
1.58\end{array}$ & $\begin{array}{r}-.0152 \\
.0317\end{array}$ & $\begin{array}{l}1.51 \\
1.99\end{array}$ \\
\hline 1984 & .0008 & 1.31 & - & - & -.0005 & .38 & -.00001 & .05 & -.0020 & 1.03 \\
\hline 1985 & .0003 & .47 & - & -- & .0008 & .65 & .0010 & 3.85 & .0025 & .82 \\
\hline 1986 & -.0020 & 2.09 & -- & - & .0055 & 2.25 & .0033 & 5.86 & .0071 & 2.00 \\
\hline 1987 & -.0035 & 3.19 & -- & -- & .0124 & 1.37 & .0040 & 3.36 & .0242 & 4.71 \\
\hline 1988 & -.0038 & 3.46 & - & -- & -.0009 & .46 & .0021 & 4.16 & .0351 & 5.78 \\
\hline 1989 & -.0016 & 1.55 & -- & -- & .0024 & .63 & .0033 & 1.64 & .0129 & 2.82 \\
\hline $\begin{array}{l}\text { R equand } \\
\text { No. Obs. }\end{array}$ & \multicolumn{2}{|c|}{$\begin{array}{l}.010 \\
9,675\end{array}$} & \multicolumn{2}{|c|}{$\begin{array}{l}.025 \\
1,528\end{array}$} & \multicolumn{2}{|c|}{$\begin{array}{l}.002 \\
9,597\end{array}$} & \multicolumn{2}{|c|}{$\begin{array}{l}.007 \\
9,597\end{array}$} & \multicolumn{2}{|c|}{$\begin{array}{l}.011 \\
9,675\end{array}$} \\
\hline
\end{tabular}

Sources: Federal Reserve Reports of Condition and Income, FDIC press releases. 
Table 4

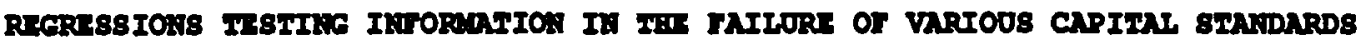

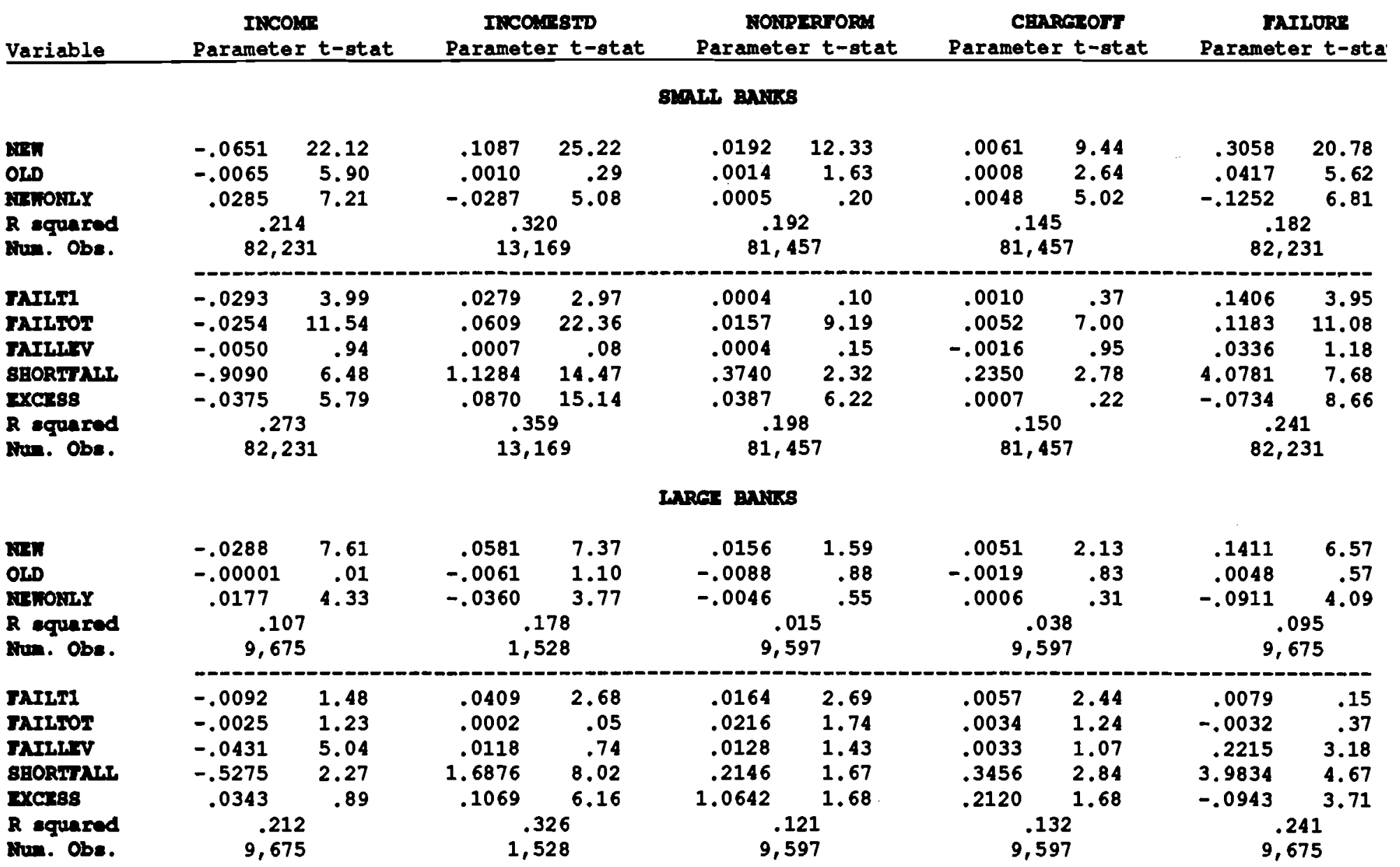

Not shown, but also included in all of these regressions are all of the variables shown in Table 3 (intercept, time dumnies, RWA20, RNA50, RKA100, COUNTER, MKTRISR, RSALEST, CEI, CONSUMTR, and COMMIT) .

Sources: Federal Reserve Reports of Condition and Income, EDIC press releases. 
rable 5

RAM DATA PRWICHIONS OF BANLROPTCY

FROM IAILORES TO MATT VARIOOS CAPITAL STANDARDS

(December 1987)

Banks That Pass or Fail

Various Capital standards

Percentage of 1987 Banks

Percentage That Were Bankrupt by the End of 1989

COMPARISONS OT MUA MND OTD CAPITAT STANDARDS

Fail new and old standards

Fail new, pass old

Fail old, pass new

Pass both standards
3.68

$2.4 \%$

1.28

$92.8 \%$
$40.7 \%$

$19.4 \%$

12.78

$1.0 \%$

\section{COAPARISONS OF PORTIOAS OF THE NEH SMANDARDS}

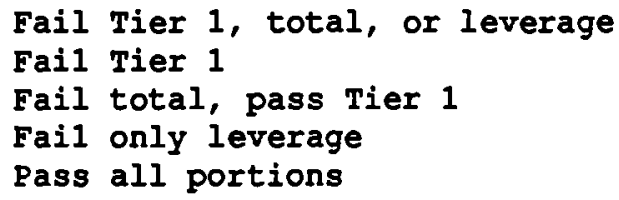

6.08

2.78

$3.2 \%$

$0.1 \%$

$94.0 \%$
$32.3 \%$

$50.4 \%$

$18.2 \%$

7.78

$1.1 \%$

Sources: Federal Reserve Reports of Condition and Income, FDIC press releases. 


\section{Table 6 \\ BANTS THAT WAII TO VEET VARIOOS CAPITAI STANDARDS \\ (December 1989)}

Number Failing Capital Standards/Total Number of Banks in the Class Percent of Total Assets Held by Banks Failing the Standards Total Capital Deficiency (\$ millions)

\begin{tabular}{|c|c|c|c|c|c|c|}
\hline $\begin{array}{l}\text { Asset size } \\
\text { Class } \\
\text { (\$ milions) }\end{array}$ & $\begin{array}{l}\text { (1) } \\
\text { Fail New }\end{array}$ & $\begin{array}{l}\text { (2) } \\
\text { Fail old }\end{array}$ & $\begin{array}{l}\text { (3) } \\
\text { Eail New } \\
\text { Pass Old }\end{array}$ & $\begin{array}{c}\text { (4) } \\
\text { Fail } \\
\text { Tier } 1\end{array}$ & $\begin{array}{l}\text { (5) } \\
\text { Fail } \\
\text { Total }\end{array}$ & $\begin{array}{c}\text { (6) } \\
\text { Fail } \\
\text { Leverage }\end{array}$ \\
\hline $0-25$ & $\begin{array}{c}174 / 3637 \\
4.8 \% \\
\$ 85\end{array}$ & $\begin{array}{c}172 / 3637 \\
4.8 \% \\
\$ 59\end{array}$ & $\begin{array}{c}35 / 3637 \\
1.08 \\
\$ 7\end{array}$ & $\begin{array}{c}96 / 3637 \\
2.78 \\
\$ 43\end{array}$ & $\begin{array}{c}170 / 3637 \\
4.78 \\
\$ 84\end{array}$ & $\begin{array}{c}110 / 3637 \\
3.08 \\
\$ 48\end{array}$ \\
\hline $25-50$ & $\begin{array}{c}134 / 3228 \\
4.18 \\
\$ 145\end{array}$ & $\begin{array}{c}143 / 3228 \\
4.38 \\
\$ 105\end{array}$ & $\begin{array}{c}27 / 3228 \\
0.98 \\
\$ 10\end{array}$ & $\begin{array}{c}70 / 3228 \\
2.18 \\
\$ 75\end{array}$ & $\begin{array}{c}133 / 3228 \\
4.18 \\
\$ 145\end{array}$ & $\begin{array}{l}78 / 3228 \\
2.48 \\
\$ 82\end{array}$ \\
\hline $50-100$ & $\begin{array}{l}78 / 2765 \\
2.7 \% \\
\$ 158\end{array}$ & $\begin{array}{c}81 / 2765 \\
2.88 \\
\$ 106\end{array}$ & $\begin{array}{c}23 / 2765 \\
0.88 \\
\$ 12\end{array}$ & $\begin{array}{c}36 / 2765 \\
1.38 \\
\$ 85\end{array}$ & $\begin{array}{c}78 / 2765 \\
2.7 \% \\
\$ 158\end{array}$ & $\begin{array}{c}36 / 2765 \\
1.38 \\
\$ 87\end{array}$ \\
\hline $100-500$ & $\begin{array}{c}110 / 2380 \\
5.08 \\
\$ 583\end{array}$ & $\begin{array}{l}71 / 2380 \\
3.28 \\
\$ 366\end{array}$ & $\begin{array}{c}64 / 2380 \\
3.08 \\
\$ 95\end{array}$ & $\begin{array}{c}35 / 2380 \\
1.58 \\
\$ 330\end{array}$ & $\begin{array}{c}109 / 2380 \\
5.08 \\
\$ 583\end{array}$ & $\begin{array}{c}33 / 2380 \\
1.58 \\
\$ 338\end{array}$ \\
\hline $500-1,000$ & $\begin{array}{l}27 / 235 \\
11.98 \\
\$ 212\end{array}$ & $\begin{array}{l}7 / 235 \\
3.3 \% \\
\$ 14\end{array}$ & $\begin{array}{c}24 / 235 \\
10.5 q \\
\$ 207\end{array}$ & $\begin{array}{c}4 / 235 \\
1.58 \\
\$ 17\end{array}$ & $\begin{array}{r}27 / 235 \\
11.98 \\
\$ 212\end{array}$ & $\begin{array}{c}2 / 235 \\
0.78 \\
\$ 8\end{array}$ \\
\hline $1,000-5,000$ & $\begin{array}{l}35 / 273 \\
12.58 \\
\$ 1,963\end{array}$ & $\begin{array}{l}6 / 273 \\
1.98 \\
\$ 712\end{array}$ & $\begin{array}{r}6 / 273 \\
10.98 \\
\$ 740\end{array}$ & $\begin{array}{c}10 / 273 \\
3.18 \\
\$ 1,088\end{array}$ & $\begin{array}{l}35 / 273 \\
12.58 \\
\$ 1,963\end{array}$ & $\begin{array}{c}8 / 273 \\
2.18 \\
\$ 1,046\end{array}$ \\
\hline $5,000-10,000$ & $\begin{array}{l}13 / 58 \\
23.18 \\
\$ 1,095\end{array}$ & $\begin{array}{r}1 / 58 \\
1.8 \% \\
\$ 22\end{array}$ & $\begin{array}{r}12 / 58 \\
21.38 \\
\$ 999\end{array}$ & $\begin{array}{l}2 / 58 \\
3.18 \\
\$ 229\end{array}$ & $\begin{array}{r}13 / 58 \\
23.18 \\
\$ 1,095\end{array}$ & $\begin{array}{l}2 / 58 \\
3.18 \\
\$ 197\end{array}$ \\
\hline$>10,000$ & $\begin{array}{c}20 / 47 \\
53.38 \\
\$ 10,816\end{array}$ & $\begin{array}{l}3 / 47 \\
5.28 \\
\$ 973\end{array}$ & $\begin{array}{r}17 / 47 \\
48.28 \\
\$ 9,671\end{array}$ & $\begin{array}{r}6 / 47 \\
9.68 \\
\$ 1,717\end{array}$ & $\begin{array}{c}20 / 47 \\
53.38 \\
\$ 10,816\end{array}$ & $\begin{array}{c}4 / 47 \\
6.88 \\
\$ 7,181\end{array}$ \\
\hline All Banks & $\begin{array}{c}591 / 12,623 \\
27.78 \\
\$ 15,058\end{array}$ & $\begin{array}{c}484 / 12,623 \\
3.68 \\
\$ 2,357\end{array}$ & $\begin{array}{c}232 / 12,623 \\
24.58 \\
\$ 11,742\end{array}$ & $\begin{array}{c}259 / 12,623 \\
5.28 \\
\$ 3,587\end{array}$ & $\begin{array}{c}585 / 12,623 \\
27.7 \% \\
\$ 15,056\end{array}$ & $\begin{array}{c}273 / 12,623 \\
3.98 \\
\$ 2,524\end{array}$ \\
\hline
\end{tabular}

Note: The 1992 risk-based capital standards are applied to December 1989 Call Report data. Sources: Federal Reserve Reports of Condition and Income, FDIC press releases. 
Table 7

BANKS THAT MOUL FAIL TO MEET INCREASED RISK-BASED CAPITAL STANDARDS (December 1989)

Number Failing Capital Standards/Total Number of Banks in the Class Percent of Total Assets Held by Banks Failing the Standards Total Capital Deficiency (\$ millions)

\begin{tabular}{|c|c|c|c|c|c|}
\hline $\begin{array}{l}\text { Asset Size } \\
\text { Class } \\
\text { ( } \$ \text { millions) }\end{array}$ & $\begin{array}{ll} & (1) \\
4 \% & \text { Tier } 1 \\
8 \% & \text { Total }\end{array}$ & $\begin{array}{ll} & (2) \\
5 \% & \text { Tier } 1 \\
9 \% & \text { Total }\end{array}$ & $\begin{array}{l}\text { (3) } \\
6 \% \text { Tier } 1 \\
10 \% \text { Total }\end{array}$ & $\begin{array}{c}(4) \\
78 \text { Tier } 1 \\
118 \text { Total }\end{array}$ & $\begin{array}{c}(5) \\
8 \% \text { Tier } 1 \\
128 \text { Total }\end{array}$ \\
\hline $0-25$ & $\begin{array}{c}174 / 3637 \\
4.88 \\
\$ 85\end{array}$ & $\begin{array}{c}221 / 3637 \\
6.28 \\
\$ 105\end{array}$ & $\begin{array}{c}293 / 3637 \\
8.28 \\
\$ 132\end{array}$ & $\begin{array}{c}428 / 3637 \\
12.18 \\
\$ 169\end{array}$ & $\begin{array}{c}593 / 3637 \\
16.98 \\
\$ 224\end{array}$ \\
\hline $25-50$ & $\begin{array}{c}134 / 3228 \\
4.18 \\
\$ 145\end{array}$ & $\begin{array}{c}181 / 3228 \\
5.58 \\
\$ 183\end{array}$ & $\begin{array}{c}279 / 3228 \\
8.68 \\
\$ 239\end{array}$ & $\begin{array}{c}430 / 3228 \\
13.48 \\
\$ 326\end{array}$ & $\begin{array}{c}635 / 3228 \\
19.88 \\
\$ 458\end{array}$ \\
\hline $50-100$ & $\begin{array}{c}78 / 2765 \\
2.78 \\
\$ 158\end{array}$ & $\begin{array}{c}142 / 2765 \\
5.18 \\
\$ 213\end{array}$ & $\begin{array}{c}260 / 2765 \\
9.48 \\
\$ 312\end{array}$ & $\begin{array}{c}436 / 2765 \\
16.08 \\
\$ 483\end{array}$ & $\begin{array}{c}648 / 2765 \\
23.98 \\
\$ 757\end{array}$ \\
\hline $100-500$ & $\begin{array}{c}110 / 2380 \\
5.08 \\
\$ 583\end{array}$ & $\begin{array}{c}238 / 2380 \\
11.58 \\
\$ 871\end{array}$ & $\begin{array}{c}437 / 2380 \\
21.18 \\
\$ 1,447\end{array}$ & $\begin{array}{l}689 / 2380 \\
32.78 \\
\$ 2,394\end{array}$ & $\begin{array}{c}973 / 2380 \\
45.18 \\
\$ 3,730\end{array}$ \\
\hline $500-1,000$ & $\begin{array}{l}27 / 235 \\
11.98 \\
\$ 212\end{array}$ & $\begin{array}{l}55 / 235 \\
23.78 \\
\$ 472\end{array}$ & $\begin{array}{c}95 / 235 \\
40.88 \\
\$ 893\end{array}$ & $\begin{array}{c}138 / 235 \\
59.18 \\
\$ 1,531\end{array}$ & $\begin{array}{c}162 / 235 \\
69.08 \\
\$ 2,330\end{array}$ \\
\hline $1,000-5,000$ & $\begin{array}{c}35 / 273 \\
12.58 \\
\$ 1,963\end{array}$ & $\begin{array}{c}87 / 273 \\
36.38 \\
\$ 3,163\end{array}$ & $\begin{array}{c}155 / 273 \\
62.18 \\
\$ 5,554\end{array}$ & $\begin{array}{c}192 / 273 \\
73.68 \\
\$ 8,874\end{array}$ & $\begin{array}{c}221 / 273 \\
83.98 \\
\$ 12,608\end{array}$ \\
\hline $5,000-10,000$ & $\begin{array}{r}13 / 58 \\
23.18 \\
\$ 1,095\end{array}$ & $\begin{array}{r}27 / 58 \\
48.28 \\
\$ 2,334\end{array}$ & $\begin{array}{r}45 / 58 \\
78.28 \\
\$ 4,709\end{array}$ & $\begin{array}{r}52 / 58 \\
90.38 \\
\$ 7,678\end{array}$ & $\begin{array}{r}56 / 58 \\
97.28 \\
\$ 10,995\end{array}$ \\
\hline$>10,000$ & $\begin{array}{c}20 / 47 \\
53.38 \\
\$ 10,816\end{array}$ & $\begin{array}{c}31 / 47 \\
65.78 \\
\$ 18,168\end{array}$ & $\begin{array}{c}42 / 47 \\
92.38 \\
\$ 28,223\end{array}$ & $\begin{array}{c}43 / 47 \\
95.88 \\
\$ 39,790\end{array}$ & $\begin{array}{c}44 / 47 \\
97.58 \\
\$ 51,736\end{array}$ \\
\hline All Banks & $\begin{array}{c}591 / 12,623 \\
27.78 \\
\$ 15,058\end{array}$ & $\begin{array}{c}982 / 12,623 \\
41.88 \\
\$ 25,509\end{array}$ & $\begin{array}{c}1606 / 12,623 \\
63.38 \\
\$ 41,508\end{array}$ & $\begin{array}{c}2408 / 12,623 \\
71,48 \\
\$ 61,246\end{array}$ & $\begin{array}{c}3332 / 12,623 \\
77.98 \\
\$ 82,838\end{array}$ \\
\hline
\end{tabular}

Note: The 1992 risk-based capital standards are applied to December 1989 Call Report data.

Sources: Federal Reserve Reports of Condition and Income, FDIC press releases. 


\section{Table 8}

REEECTS OF THE REMOVAL OF KEY ASPECTS OF RISK-BASED CAPITAL AND BANK PORTEOLIO REACTIONS TO RISK-BASED CAPITAL.

(December 1989)

Number Failing Capital Standards/Total Number of Banks in the Class

Percent of Total Assets Held by Banks Failing the Standards Total Capital Deficiency (\$ millions)

Calculation

Al1

Assets $>$

Banks $\$ 10$ Billion

Complete 1992 RBC standards

$591 / 12,623$

$20 / 47$

applied to 1989 portfolios

27.78

53.38

$\$ 15,058$

$\$ 10,816$

\section{A. Remoral of Key Aspects of Risk-Based Capital}

1. Removal of unequal weighting of on-balance sheet assets

2. Removal of off-balance sheet activities

3. Removal of increase in capital required over old standards

4. Removal of new treatment of loan loss reserves in capital categories
$597 / 12,623$

19.08

$15 / 47$

$\$ 8,526$

$915 / 12,623$

25.68

$\$ 11,067$

$481 / 12,623$

23.48

$\$ 11,347$

$416 / 12,623$

16.58

$\$ 7,290$
38.38

$\$ 5,124$

$12 / 47$

36.28

$\$ 5,664$

$16 / 47$

47.38

$\$ 7,829$

$11 / 47$

31.48

$\$ 4,860$

\section{B. Potential Portfolio Reactions to Risk-Based Capital}

5. On-balance sheet adjustments (eliminating 108 of the 100 percent risk category assets)

6. Off-balance sheet adjustments (eliminating $50 \%$ of loan commitments and 508 of standbys to nonfinancial firms)

7. On- and off-balance sheet adjustments combined
$437 / 12,623$

$$
21.48
$$

$\$ 10,606$

$544 / 12,623$

22.48

$\$ 10,582$

$409 / 12,623$

14.68

$\$ 7,308$
$14 / 47$

43.78

$\$ 7,301$

$14 / 47$

44.08

$\$ 6,954$

$9 / 47$

28.98

$\$ 4,428$

Note: The 1992 risk-based capital standards are applied to December 1989 Call Report data.

Sources: Federal Reserve Reports of Condition and Income, FDIC press releases. 